\title{
The cutaneous radiation syndrome: diagnosis and treatment
}

\author{
R.U. PETER ${ }^{\mathrm{l}}$, M. STEINERT ${ }^{1}$, P. GOTTLÖBER $^{1}$
}

ABSTRAC'T Accidental exposure to ionising radiation may occur during such catastrophic events as the Chernobyl accident in 1986 or for days and weeks as in Goiania in 1987 and in the military camp during the training of soldiers in Lilo/Georgia in 1997 as well as in medical institutions. The cutaneous symptoms after radiation exposure are based on a combination of inflammatory processes and alteration of cellular proliferation as a result of a specific pattern of transcriptionally activated proinflammatoric cytokines and growth factors. They follow a time course consisting of prodromal erythema, manifestation, chronic stage, late stage and they are referred to as Cutaneous Radiation Syndrome. The time course depends on several factors such as the applied radiation dose, radiation quality, individual radiation sensitivity, the extent of contamination and absorption and volume of the skin. For diagnostics of the cutaneous radiation syndrome the following procedures are used: $7.5 \mathrm{MHz}$ to $20 \mathrm{MHz}-\mathrm{B}$-scan-sonography, thermography, capillary microscopy, profilometry, nuclear magnetic resonance imaging, bone scintigraphy and histology. Based on the results of experimental and clinical research of the last years pharmacotherapy of the cutaneous radiation syndrome includes topic or systemic application of corticosteroids, gamma-interferon, pentoxifylline and vitamin $\mathbf{E}$ and superoxide dismutase. The treatment depends on the stage of the cutaneous radiation syndrome. Due to the complexity of the clinical manifestations of radiation disease in most patients an interdisciplinary treatment in specialised centres is necessary. Dermatologists are asked to perform in most cases life-long therapy and follow-up of the patients.

RÉSUMÉ Le syndrome d'irradiation cutané, diagnostic et traitement.

Une exposition accidentelle aux rayonnements ionisants peut arriver durant des événements catastrophiques comme l'accident de Tchernobyl en 1986, Goiânia en 1987, Lilo (Georgie) en 1997 mais aussi dans des installations médicales. Le syndrome cutané après exposition aux rayonnements est basé sur la combinaison d'un processus inflammatoire et l'altération de la prolifération cellulaire, par la voie d'activation de cytokines proinflammatoires et de facteurs de croissances. Is succèdent à une phase d'érythème prodromique, puis manifeste, d'une phase chronique pour finalement devenir le syndrome d'irradiation cutané. Le temps d'apparition dépend de plusieurs facteurs, tels que la dose, le type de rayonnement, la sensibilité individuelle, l'étendue de la surface et du volume de peau contaminée ou irradiée. Pour les diagnostics du syndrome d'irradiation cutané, la procédure suivante est utilisée : de 7,5 $\mathrm{MHz}$ à $20 \mathrm{MHz}-\mathrm{B}$ scanographie, thermographie, microscopie capillaire, profilométrie, imagerie RMN, scintigraphie osseuse et histologie. Sur la base des résultats expérimentaux et des recherches cliniques de ces dernières années, la pharmacothérapie de ce syndrome implique corticostéroïdes,

\footnotetext{
${ }^{I}$ Department of Dermatology, University of Ulm and Armed Forces Hospital Ulm, Ulm, Germany.
} 
interféron gamma, pentoxifylline, vitamine $\mathbf{E}$ et superoxyde dismutase. Le traitement dépend de l'évolution du syndrome. Due à la complexité des manifestations de la maladie liée à l'irradiation chez la plupart des patients, un traitement interdisciplinaire dans des centres spécialisés est nécessaire. Les dermatologues sont sollicités pour des thérapies très longues et pour le suivi des patients.

\section{Introduction}

Ionising radiation causes severe acute and chronic reactions in skin. In contrast to older viewpoints focussing mainly on the antiproliferative effects of ionising radiation on hypothetical stem cells, recent scientific progress demonstrated that these radiation-induced cutaneous reactions are caused by complex interactions between anti-proliferative and proinflammatory processes, involving a variety of cytokines and adhesion molecules, in a clinically well-defined time pattern, for which the term cutaneous radiation syndrome (CRS) has been coined (Peter, 1993; 1996).

\section{Clinics}

Generally, the course of cutaneous radiation syndrome (CRS) follows a distinct clinical pattern. The stages of CRS are summarised in Table I. Within minutes to hours after exposure an erythematous rash develops, which may be associated with burning itch (Peter, 1993; 1996). This prodromal stage is transient in nature. The manifestation stage is characterised by erythema and eventually discrete scaling. In severe cases, subepidermal blisters and ulcers may develop. Among the chronic sequelae xerosis, hyper- and hypopigmentation are characteristic features, apart from epidermal atrophy, radiation fibrosis, radiation keratosis, ulcers, teleangiectasias, radiation lentigo and subungual splinter hemorrhages (Peter, 1993; 1996; Peter et al., 1997). Basal and squamous cell carcinomas may develop (Gottlöber

\section{TABLE I}

Clinical stages of the cutaneous radiation syndrome (Peter, 1993; Gottlöber, 2000).

Phases cliniques du syndrome d'irradiation cutané (Peter, 1993 ; Gottlöber, 2000).

\begin{tabular}{|c|c|c|c|}
\hline stage & latency & persistence & symptoms \\
\hline prodromal stage & minutes-hours & $0.5-36$ hours & erythema, pruritus \\
\hline manifestation stage & 3 weeks & 1-2 weeks & erythema, pruritus, bullae, ulcer \\
\hline subacute stage & 16 weeks & months & erythema, ulcer \\
\hline chronic stage & years & unlimited & $\begin{array}{l}\text { keratosis, fibrosis, ulcer epidermal atrophy, } \\
\text { teleangiectasias, } \\
\text { hyper-and hypopigmentation }\end{array}$ \\
\hline late stage & $>10$ years & unlimited & $\begin{array}{l}\text { ulcer, epidermal atrophy, angioma, } \\
\text { basal and squamous cell carcinomas }\end{array}$ \\
\hline
\end{tabular}


et al., 1999). The time course depends on several factors such as the applicated radiation dose, radiation quality, individual radiation sensitivity, the extent of exposure, contamination and absorption and volume of the skin.

\section{Diagnosis}

For diagnostics of the cutaneous radiation syndrome the following procedures are used: $7.5 \mathrm{MHz}$ to $20 \mathrm{MHz}-\mathrm{B}-\mathrm{scan}$-sonography, thermography, capillary microscopy, profilometry, nuclear magnetic resonance imaging, bone scintigraphy and histology (Gottlöber et al., 2000).

The $20 \mathrm{MHz}$-sonography is a frequently used, reproducible, non-invasive method for evaluation of skin thickness and skin density in patients with cutaneous radiation fibrosis (Fornage et al., 1993; Gropper et al., 1993; Gottlöber et al., 1997). The $20 \mathrm{MHz}$-scanner with an axial resolution of about $80 \mu \mathrm{m}$ and a lateral resolution of $200 \mu \mathrm{m}$ is suitable to investigate epidermis, dermis and subcutaneous fat tissue up to a depth of about $10 \mathrm{~mm}$. The depth of cutaneous radiation ulcers can be determined by sonography before and during therapy. The $7.5 \mathrm{MHz}-$ sonography is a well established, non-invasive procedure for evaluation of dermis, subcutaneous fat tissue, muscle fascia and musculature. Radiation fibrosis of subcutis and deeper radiation ulcers can be determined by $7.5 \mathrm{MHz}$-sonography (Gottlöber et al., 2000; Fornage et al., 1993; Gropper et al., 1993; Gottlöber et al., 1997).

Thermography is a useful method for quantification of the skin temperature and heat loss of the body (Köteless et al., 1998). The skin surface temperature and the emitted heat from the body surface are connected with the cutaneous vessel system. The measurement of the skin surface temperature and heat loss from the skin is an indirect parameter for the vascularisation of the skin. Such techniques like infrared thermogaphy, microwave thermography and liquid-crystal-contactthermography are available (Gottlöber et al., 2000; Köteless et al., 1998). There is a significant lower local skin surface temperature in patients with necrosis. A significant higher skin temperature was observed in patients with inflammations (Gottlöber et al., 2000; Köteless et al., 1998).

Capillary microscopy is a non-invasive method for a qualitative and quantitative evaluation of the capillaries of the stratum papillare of the dermis (Bahmer, 1992). The capillaries of the nail fold of fingers or feet are dilated in patients with the manifestation stage of CRS. The capillaries are smaller and rare in patients with the chronic stage of CRS (Bahmer, 1992). Additionally subungual 
splinter hemorrhages may visible in distal parts of the nail bed in these stages (Peter et al., 1994).

Profilometry is the most common method to quantify the skin topography in two and three dimensions (Gottlöber et al., 2000). The analysis of the vertical and horizontal distribution of the furrows gives information on skin surface.

Nuclear magnetic resonance imaging is a non-invasive, well-established approach for the examination of the signal intensity of dermis, subcutaneous fat tissue, muscle and bone (Gottlöber et al., 2000). Morphological changes can be discovered. The increase of the signal intensity in the nuclear magnetic resonance imaging is the result of fluid in the tissue that may occur through inflammation, oedema or necrosis. A reduced content of fluid in the tissue leads to a decrease of signal intensity (Gottlöber et al., 2000). With nuclear magnetic resonance imaging the extent of skin ulcers in radiation exposed patients could be evaluated. A disadvantage of this method is the lacking ability to discriminate between necrosis and inflammation.

Bone scintigraphy allows information about the activity in bone under radiation ulcers (Gottlöber et al., 2000).

Histology is an invasive method for determination of CRS. The histology of the manifestation stage/subacute stage of CRS demonstrates dilated blood vessels, oedema and multiple infiltrations consisting mainly of neutrophils and eosinophils. The histology of the chronic stage/late stage of CRS is characterised by epidermal atrophy or akanthosis, fibrosis of the dermis, rare lymphohistiocytic infiltrations, dilated blood and lymphatic vessels in the upper dermis, hypo- and hyperpigmentation and a loss of skin appendices (Peter, 1996; Gottlöber et al., 2000).

The exposure to high single radiation doses affects the reproductive system (Peter, 1993; 1996; Gottlöber et al., 2000a; 2000b). After total doses of more than 1.5 Gy persistent azoospermia is to be expected (Gottlöber et al., 2000a). In radiation exposed patients a semen analysis should be performed. Furthermore, blood levels of luteinizing hormone (LH), follicle stimulating hormone (FSH), testosterone and prolactin should be measured (Gottlöber et al., 2000a; 2000b).

\section{Treatment}

\subsection{Conservative treatment}

Treatment has to focus on the stage of CRS and the avoidance of additional risk to the patients (Gottlöber et al., 2000b). The therapeutic regime is summarised in Table II. 


\section{TABLE II}

Conservative treatment (Gottlöber et al., 2000).

Traitement conservatif (Gottlöber et al., 2000).

\begin{tabular}{|c|c|}
\hline stage & treatment \\
\hline prodromal stage & $\begin{array}{l}\text { basic therapy with linoleic creams or lotio alba, nonatrophogenic } \\
\text { steroids, antihistamine }\end{array}$ \\
\hline manifestation stage/subacute stage & $\begin{array}{l}\text { topical/systemic steroids, tetrachlorodekaoxide, thrombocytic } \\
\text { growth factors, hydrocolloid dressings, antibiotic prophylaxis, } \\
\text { analgesics }\end{array}$ \\
\hline chronic stage & $\begin{array}{l}\text { basic therapy with linoleic acid, topical/systemic retinoids, } \\
\text { interferon gamma, systemic/topical application of superoxide } \\
\text { dismutase, systemic application of pentoxifylline and } \\
\text { alpha-tocopherol tetrachlorodekaoxide, thrombocytic growth } \\
\text { factors, hydrocolloid dressings, semisynthetic dressings } \\
\text { (Integra), analgesics }\end{array}$ \\
\hline late stage & $\begin{array}{l}\text { treatment like in the chronic stage, excision of basal } \\
\text { and squamous cell carcinomas }\end{array}$ \\
\hline
\end{tabular}

The prodromal and manifestation stages are characterised by inflammatory processes (Gottlöber et al., 2000). Antiinflammatoric creams e.g. linoleic acid (Linola $\mathrm{Fet}^{\mathrm{R}}$, Wolff, Bielefeld) cream should be used as basic treatment. Additionally, nonatrophogenic local steroids e.g. Mometasonfuroate $\left(\right.$ Ecural $^{\mathrm{R}}$, Elocon $^{\mathrm{R}}$, Schering-Plough, New Jersey) should be used to reduce the inflammation (Peter, 1996; Gottlöber et al., 2000a; 2000b; Peter et al., 1996). Systemic steroids $(0.5-1.0 \mathrm{mg} / \mathrm{kg}$ prednisolon equivalent) should be applied in patients with extensive affected skin areas after check of contraindications to reduce the dermal and muscular vasculitis (Peter, 1996; Gottlöber et al., 2000a; 2000b; Peter et al., 1996). If the patients suffer from pain, analgetics should be given. Treatment with loratadine, $\left(\right.$ Lisino $^{\mathrm{R}}$, Schering-Plough, New Jersey) a nonsedating and mast cell stabilising antihistamine, induce a marked relief of burning itch (Gottlöber et al., 2000; Peter et al., 1994; 1996b). Additional therapy modalities which have been reported to be of value in the manifestation stage are heparinization and antibiotic prophylaxis for bacterial infections (Gottlöber et al., 2000a; 2000b; Peter et al., 1994; 1996).

Xerosis is one of the symptoms of the chronic stage of CRS. The basic therapy with a specific ointment containing linoleic acid (Linola Fett ${ }^{\mathrm{R}}$, Wolff, Bielefeld) lead to a marked decrease of initially severely increased transepidermal water loss. Teleangiectasias caused discomfort due to sensation of a burning itch and heat, which disappeared after therapy by argon laser (Gottlöber et al., 2000a; Peter et al., 1994; 1996).

Tretinoin cream $0.005 \%$ (Epi Aberel ${ }^{\mathrm{R}}$, Janssen Cilaf, Germany), applied once daily, lead to a clearance of focal and patchy radiation keratoses (Gottlöber et al., 
2000a; Peter et al., 1994; 1996). In more extensive lesions, oral application of retinoids should be recommended (Gottlöber et al., 2000a; Peter et al., 1994; 1996).

Radiation fibrosis is characterised by an increase of collagen fibres by affected fibroblasts. If left untreated, persistent cutaneous fibrosis may give rise to ulceration. Various approaches have been undertaken to antagonise this chronically inflammatory process, among these systemic and topical application of superoxide dismutase, systemic application of pentoxifylline and alpha-tocopherol and proteinase inhibitors (Lefaix et al., 1993; 1996; 1999; Gottlöber et al., 1996).

Interferon gamma inhibits collagen production by human dermal fibroblasts (Peter et al., 1999). Interferon gamma should be scheduled on a low-dose regimen, $2-3 \times 100 \mu \mathrm{g} /$ week s.c. for 6 months, then once per week for another 6 months. A decrease in skin thickness could be observed 6 months after initiation of therapy (Peter et al., 1999; Gottlöber et al., 2001).

Cutaneous radiation ulcer should be treated with topical dressings of tetrachlorodekaoxide (TCDO). TCDO induce considerable granulation and reepithelization in ulcers. Additionally, hydrocolloid dressings or topical thrombocytic growth factors could be used (Gottlöber et al., 2000a; Peter et al., 1996). A recent interesting alternative is wound dressings with semipermeable fibres $\left(\right.$ Biocell $^{\mathrm{R}}$, Germany) a systematic evaluation of this new approach is pending. Integra, another semi-synthetic skin equivalent has effectively been used to cover large surgically removed radionecrotic skin (Carsin, personal communication).

\subsection{Surgical treatment}

If the conservative therapy of radiation ulcers or radiation fibrosis is not successful, a surgical treatment should be performed.

Surgical procedures include the excision of ulcers or fibrosis, primary wound closure or split or full thickness skin grafts or vascularized flaps (Marks et al., 1992; Rieck et al., 1996). The detailed surgical procedures are summarised in the manuscript of Dr. Carsin.

\section{REFERENCES}

Bahmer F. (1992) Die Nagelfalzkapillaroskopie in der Dermatologie, Hautarzt 43, 314.

Fornage B.D., McGravan M.H., Duvic M., Waldron C.A. (1993) Imaging of the skin with 20-MHz US, Radiology 189, 69-76.

Gottlöber P. et al. (1996) Treatment of cutaneous radiation fibrosis with Pentoxifylline and Vitamin E - A case report (in German), Strahlenther Onkol 172, 34-38. 


\section{THE CUTANEOUS RADIATION SYNDROME: DIAGNOSIS AND TREATMENT}

Gottlöber P., Kerscher M., Korting H.C., Peter R.U. (1997) Sonographic determination of cutaneous and subcutaneous fibrosis after accidential exposure to ionizing radiation in the course of the chernobyl nuclear power plant accident, Ultrasound Med. Biol. 23, 9-13.

Gottlöber P., Bezold G., Krähn G., Peter R.U. (1999) Basal cell carcinomas occurring after exposure to ionising radiation, $B r$. J. Dermatol. 141, 383-385.

Gottlöber P., Krähn G., Peter R.U. (2000a) The Cutaneous Radiation Syndrome: Clinics, diagnostics and therapy (in German), Hautarzt (in press).

Gottlöber P., Bezold G., Weber L., Gourmelon P., Cosset J.M., Bähren W., Hald H.J., Fliedner T.M., Peter R.U. (2000b) The radiation accident in Georgia-Clinical appearance and diagnostics of Cutaneous Radiation Syndrome, J. Am. Acad. Dermatol. 42, 453-458.

Gottlöber P., Steinert M., Bähren W., Weber L., Gerngroß H., Peter R.U. (2001) Interferon-gamma in five patients with cutaneous radiation syndrome, Int. J. Radiat. Oncol. Biol. Phys. 50, 159-166.

Gropper C.A., Stiller M.H., Shupack J.L. (1993) Diagnostic high-resolution ultrasound in dermatology, Int. J. Dermatol. 32, 243-249.

Köteles G.J., Benkö I., Nemeth G. (1998) Use of thermography in diagnosis of local radiation injuries Health Phys. 74, 264-265.

Lefaix J.L. et al. (1993) La fibrose cutaneo-musculaire radio-induite (III): efficacite therapeutique majeure de la superoxyde dismutase $\mathrm{Cu} / \mathrm{Zn}$ liposomiale, Bull. Cancer 80, 799-807.

Lefaix J.L. et al. (1996) Successful treatment of radiation-induced fibrosis using Cu-Zn SOD and MnSOD: An experimental study, Int. J. Radiat. Oncol. Biol. Phys. 35, 305-312.

Lefaix J.L. et al. (1999) Striking regression of subcutaneous fibrosis induced by high doses of gamma rays using in a combination pentoxifylline and tocopherol: an experimental study, Int. J. Rad. Oncol. Biol. Phys. 43, 839-847.

Marks S.L., Song M.D., Stannard A.A., Power H.A.T (1992) Clinical evaluation of etretinate for the treatment of canine solar-induced squamous cell carcinoma and preneoplastic lesions, J. Am. Acad. Dermatol. 27, 11-16.

Peter R.U. (1993) Klinische Aspekte des kutanen Strahlensyndroms nach Strahlenunfällen Erfahrungen von Goiania und Tschernobyl, Akt. Dermatol. 19, 364-367.

Peter R.U., Braun-Falco O., Biriukov A., Hacker N., Kerscher M., Peterseim U., Ruzicka T., Konz B., Plewig G. (1994) Chronic cutaneous damage after accidential exposure to ionizing radiation: The Chernobyl experience, J. Am. Acad. Dermatol. 30, 719-723.

Peter R.U. (1996) The cutaneous radiation syndrome. In: Advances in the treatment of radiation injuries (MacVittie T., Browne D., Weiss J., Eds.), pp. 237-240. Elsevier, Oxford.

Peter R.U., Gottlöber P., Heckmann M., Braun-Falco O., Plewig G. (1996) Treatment and follow-up of patients suffering from the cutaneous radiation syndrome. In: The radiological consequences of the chernobyl accident (Karaoglou A., Desmet G., Kelly G.N., Menzel H.G., Eds), pp. 601-605. Publications of the European Commission, Brüssel.

Peter R.U., Gottlöber P., Nadeshina N., Krähn G., Plewig G., Kind P. (1997) Radiation lentigo: a distinct cutaneous lesion after accidental radiation exposure, Arch. Dermatol. 133, 209-211.

Peter R.U., Gottlöber P., Krähn G., Nadejina N., Braun-Falco O., Plewig G. (1999) Gamma-interferon in survivors of the Chernobyl power plant accident- new therapeutic option for radiation induced fibrosis, Int. J. Radiat. Oncol. Biol. Phys. 45, 147-152.

Rieck B., Mailander P., Berger A. (1996) Plastic surgery therapy of infected and clean radiation ulcersproblem wounds as the responsibility of plastic surgery, Zentralbl. Chir. 121, 61-64. 